\begin{tabular}{|lll|}
\hline Volume 24 & No. 1, Juni 2018 & Halaman 65-72 \\
\hline
\end{tabular}

\title{
WAKTU, RUANG, DAN SEJARAH DALAM NOVEL BOERON DARI DIGOEL
}

\section{(Time, Space, and History in Boeron dari Digoel Novel)}

\author{
Asep Rahmat Hidayat \\ Balai Bahasa Jawa Barat \\ Jalan Sumbawa Nomor 11, Bandung, Jawa Barat, Indonesia \\ Pos-el: asep.rahmat@kemdikbud.go.id \\ Diterima: 12 Februari 2018; Direvisi: 5 Juni 2018; Disetujui: 5 Juni 2018
}

\begin{abstract}
Historical literature is a literary work that contains elements of history. Novel of Boeron dari Digoel includes a historical novel written by historical figures. This study aims to reveal the way of time and space narrated by the author, so the historical aspect revealed from the novel. The method used is qualitative method with content analysis technique. The result shows the time narrated in the colonial period between 1927-1929. Space is narrated in the region of Boven Digul in Papua. Both aspects reveal the history of political exile of Indonesian historical figures to Boven Digul committed the Dutch East Indies colonial government. The struggle was experienced by the novelist Boeron of Digoel.
\end{abstract}

Keywords: historical novel; space; time; history.

\begin{abstract}
Abstrak
Sastra sejarah merupakan karya sastra yang memuat unsur sejarah. Novel Boeron dari Digoel termasuk novel sejarah yang ditulis oleh tokoh sejarah. Penelitian ini bertujuan untuk mengungkap cara waktu dan ruang dinarasikan oleh penulis sehingga aspek sejarah terungkap dari novel tersebut. Metode yang digunakan adalah metode kualitatif dengan teknik analisis isi. Hasil penelitian menunjukkan bahwa waktu yang dinarasikan merujuk pada masa kolonial antara tahun 1927-1929. Ruang yang dinarasikan merujuk pada wilayah Boven Digul di Papua. Kedua aspek itu mengungkap sejarah pembuangan tokoh sejarah Indonesia ke Boven Digul oleh pemerintah kolonial Hindia Belanda.Pembuangan itu dialami sendiri oleh penulis novel Boeron dari Digoel.
\end{abstract}

Kata kunci: novel sejarah; ruang; waktu; sejarah.

\section{PENDAHULUAN}

Kaitan sastra dan sejarah sudah menjadi bahan perdebatan para filsuf awal. Perdebatan itu berkisar pada pembahasan: sastra menceritakan peristiwa yang mungkin terjadi, sedangkan sejarah menceritakan peristiwa-peristiwa yang sudah terjadi (Ratna, 2010:331).

Karya-karya sastra yang berisi sejarah kemudian lahir dan berkembang. Karya-karya tersebut ada yang ditulis oleh pelaku sejarah sendiri maupun oleh penulis lain. Penelitian terhadap novel-novel sejarah sudah dilakukan. Hidayat (2016: 89-99) meneliti aspek-aspek sejarah dan budaya masyarakat Dayak dalam artikel "Dayak Abad Ke-19 dalam Novel Disersi". Wildan dkk. (2015:25-36) meneliti aspek-aspek sejarah Aceh dalam artikel "FaktaSejarahdalam Novel Perempuan Keumala Karya Endang Moerdopo". Kemudian, Wiyatmi meneliti aspek-aspek sejarah sosial politik dalam laporan penelitian yang berjudul Representasi Sejarah Sosial Politik Indonesia dalam Novel-Novel Karya Ayu Utami (2012). 
Penelitian-penelitian tersebut ada yang menggunakan data berupa karya sastra yang tidak merujuk langsung pada satu kurun waktu atau peristiwa sejarah tertentu. Sementara data yang digunakan dalam penelitian ini merujuk pada satu kurun waktu dalam sejarah, bahkan ditulis oleh pelaku sejarah.

Peristiwa pengasingan Digul juga merupakan peristiwa yang penting pada awal pergerakan kemerdekaan. Namun, peristiwa itu belum dikaji dalam aspek kesastraannya.

Penelitian ini bertujuan untuk meneliti cara waktu dan ruang dinarasikan oleh penulis, sehingga aspek sejarah terungkap dalam novel Boeron dari Digoel. Penelitian ini memiliki kesamaan dengan penelitian tersebut, yaitu menggunakan novel sejarah sebagai sumber data. Namun, novel yang menjadi sumber data berbeda dengan penelitian tersebut.

\section{KERANGKA TEORI}

Karya sastra dan sejarah berbeda secara keilmuan tetapi keduanya saling melengkapi. Sejarawan fokus pada peristiwa mewujud dalam ruang dan waktu tertentu yang pada prinsipnya dapat diamati atau dirasakan, sedangkan penulis imajinatif memperhatikan peristiwa dan hal lain yang dapat diimajinasikan, dihipotetiskan, atau diciptakan dari peristiwa itu sendiri. Oleh karena itu, yang menarik adalah sejauh mana wacana sejarawan dan gagasan penulis imajinatif tumpang tindih, menyerupai, atau berhubungan satu sama lain (Llewellyn, 2007: 4).

Hadirnya sejarah dalam narasi sastra memunculkan pula istilah metafiksi historiografis (historiographic metafiction) sebagai satu teori kritik dalam narasi tersebut. Pencetusnya, Linda Hutcheon, menjelaskan bahwa istilah itu menyangkal metode natural atau akal sehat (common-sense) untuk membedakan antara fakta historis dan fiksi. Ini menolak pandangan bahwa hanya sejarah yang memiliki klaim kebenaran, baik dengan mempertanyakan dasar klaim tersebut dalam historiografi dan dengan menyatakan bahwa baik sejarah maupun fiksi adalah wacana, konstruksi manusia, sistem yang menandakan, dan keduanya memperoleh klaim utama mereka atas kebenaran dari identitas itu (Hutcheon, 2004: 93).

Berkaitan dengan novel sejarah, Kuntowijoyo (1987: 133) menyatakan lahirnya novel sejarah di Indonesia merupakan pendukung gerakan nasionalisme dalam menentang kolonialisme. Novel Boeron dari Digoel juga selaras dengan pendapat itu. Novel ini ditulis oleh tokoh yang dianggap sebagai penentang kolonialisme. Penulis diasingkan ke Boven Digul oleh pemerintah Hindia Belanda.

Hubungan antara sastra dan sejarah setidaknya berkisar pada tiga masalah yaitu (1) Relevansi fakta-fakta sejarah, dalam hal ini berkaitan dengan isi; (2) Homologi unsur-unsur, dalam hal ini berkaitnan dengan struktur dan (3) Relevansi proses kreatif dalam hal ini berkaitan dengan perkembangan genre sastra (Ratna, 2010: 348)

\section{METODE}

Penelitian ini menggunakan metode kualitatif dengan teknik analisis isi. Teknik analisis isi dilakukan untuk mengumpulkan dan menganalisis isi teks. Isi teks berupa kata-kata, makna, gambar, simbol, ide, tema, atau pesan apapun yang dapat dikomunikasikan. Teks adalah semua yang tertulis, tergambarkan, atau tertuturkan yang menjadi media komunikasi (Neuman, 2003: 310). Dengan kata lain, Coser (1991:56) mengemukakan bahwa studi yang berdasarkan pada analisis isi menggunakan dokumen sebagai pangkalan data. Dengan menganalisis isi dokumen (surat kabar, karya sastra, karya seni, dokumen personal, peneliti dapat menyelami nilai budaya dan kondisi sosial dalam masyarakat tertentu.

Teknik analisis isi diterapkan dengan membaca, memilah, mencatat, menganalisis, dan menggunakan data. Ada dua jenis teks, yaitu teks novel Boeron dari Digoel sebagai sumber utama dan teks nonsastra sebagai sumber sekunder. 


\section{PEMBAHASAN}

Novel Boeron dari Digul yang dijadikan data penelitian diterbitkan oleh Tamboer Press pada tahun 2000. Novel ini diterbitkan pertama kali oleh DrukkerijLitera, Bandung, tanpa tahun terbit. Sementara itu menurut Toer (2001: x) novel ini diterbitkan dengan judul Antara Hidup dan Mati atau Buron dari Boven Digul oleh penerbit Bulan Purnama di Bandung pada tahun 1931.

Novel ini dibagi dalam 9 bagian, "Empat Mata", "Ia Punya Bini”, "Hari Kesatu”, “Zwarte Waterkoorts", "Bahaya Banjir", "Pertemuan", "Percobaan Makan Daging Ular", "Perjalanan di Kali Kay", dan "Pulang di Asal". Novel ini berkisah tentang pelarian tujuh orang buangan dari Boven Digul.

"Satujalan yang kita bisa lolos dari itu cengkeraman nasib...ia...lah!"

"Apa?" Kamlintanya.

"Kita bisa buron dari sini!" jawabSoedjito (Wiranta, 2000: 6).

Soedjito adalah penggagas pelarian ini. Gagasan itu semula mendapat tantangan dari kawannya sendiri. Kamlin, misalnya, menganggap ide itu sebagai ide gila dan hanya impian karena risiko yang akan dihadapi seperti penyakit, binatang buas, kelaparan.

\section{Waktu}

Waktumenurut Kristeva ada dua jenis, yaitu waktu siklus (pengulangan) dan monumental (kekekalan), yang terkait dengan peran keibuan, reproduksi dan jouissance perempuan, serta waktu linier. Waktu linier adalah jenis waktu terkait dengan sejarah, politik, catatan resmi dan tatanan simbolik. Karena tatanan simbolis adalah urutan komunikasi verbal, waktu linier terdiri atas ucapan kalimat, masing-masing menjadi urutan kata, memiliki tujuan, pesan, awal dan akhir (Llewellyn, 2007: 60).

Berdasarkan hal itu, waktu yang akan diungkap dalam novel ini adalah waktu linier. Waktu yang diwujudkan dalam tuturan verbal dalam novel.
Novel ini dibuka dengan percakapan antara tokoh Soedjito dan Amat.

"Apa sampean bisa berenang?"

"Bisa saja, kalau di kali yang cetek."

"Lho...! Ini betul-betul...,yang dibilang saya bisa berenang itu, kalau sampean bisa berenang dalam tempo 2 atau 3 jam terus menerus."

"Kalau begitu, bagaimana dan...?"

"Bukan, kalauumpamanyanyeberangin kali Digul, sampean sanggup?"

"Kalau Cuma nyebrangin saja, ya...rasarasanya sanggup juga." (Wiranta, 2000:1-2)

Soedjito menanyakan kesanggupan Amat berkaitan dengan rencananya untuk melarikan diri dari Digul. Dalam kutipan itu muncul aspek waktu "2 atau 3 jam" yang bersanding dengan aspek ruang "kali Digul". Melalui dua hal itu penulis membangun narasi bahwa Digul itu satu daerah yang luas, sehingga untuk menyeberangi kalinya diperlukan waktu 2 sampai 3 jam berenang terus menerus.

Narasi itu diperkuat dengan penanda waktu dalam kutipan lain. Perlu waktu lebih dari empat hari untuk keluar dari Digul.

Dalam tempo perjalanan ke empat hari sudah terdapat dua bahaya, bahaya semakin jauh semakin besar saja (Wiranta, 2000: 46)

Setelah menempuh empat hari perjalanan, pelarian itu masih berada di belantara Digul. Penanda waktu yang dimunculkan itu memberikan gambaran luasnya Digul. Keluasan wilayah itu disertai dengan berbagai bahaya. Dua di antaranya sudah mereka alami. Pertama, munculnya bajul atau buaya dari dalam sungai yang hampir membalikkan perahu mereka dan menyebabkan 15 kati beras perbekalan terhanyut (Wiranta, 2000:31). Kedua, penyakit zwarte waterkoorts atau kencing hitam. Penyakit ini merenggut seorang pelarian, Soewirdjo, karena dia lupa meminum tablet anti malaria (Wiranta, 2000: 41).

Selanjutnya, penulis mengungkapkan unsur waktu lainnya untuk menguatkan lagi lamanya waktu yang diperlukan untuk keluar dari rimba raya Digul. 
Dan kalau sudah sampai di muara...ya, saya kira Cuma dengan ambil tempo 18 jam perjalanan perahu..., baru kita nginap di sana buat satu malam..., dan besoknya kita naik dengan perahu juga, kira-kira dalam tempo 3 hari kita bisa sampai di sini... (Wiranta, 2000:7)

Setelah itu perahu ambil perjalanan 7 jam, dengan Cuma berhenti satu kali saja (Wiranta, 2000: 54).

Mereka harus mengayuh perahu selama 18 jam setiap hari untuk sampai ke muara sungai Digul.

Sebelum memutuskan untuk melakukan pelarian bersama. Soedjito dan keenam temannya berunding terlebih dahulu untuk mematangkan rencana.

"Besok siang kira-kira pukul 9 kita musti kumpul di hutan...kita akan rembuk sampai matang betul-betul (Wiranta, 2000: 24).

Mengapa pertemuan itu harus dilakukan pukul 9? Ternyata aspek waktu tersebut memiliki makna yang merujuk pada aspek ruang juga. Pada pukul 9 penghuni tempat pengasingan Digul sedang tidur atau berada di bilik masingmasing, sehingga kerahasiaan pembicaraan mereka terjaga.

Yang biasanya ia pukul 9 sudah tarik selimut, karena di sana bukan saja tidur siang-siang itu adalah satu kebiasaan, tapi memang menurut perintah dokter berhubung dengan nyamuk malaria, yang mana itu nyamuk mulai jam itu melayang sana-sini buat cari korbannya (Wiranta, 2000:14).

Angka 9 yang menjadi petunjuk waktu menguatkan pada aspek ruang dalam novel itu. Pukul 9 menjadi penanda selanjutnya pada tempat yang bernama Digul. Digul dalam konteks itu meskipun tidak disebut berada di Papua dikuatkan oleh narasi tentang malaria yang memang khas daerah timur, termasuk Papua.

Kapankah pelarian itu berlangsung? Penulis memberi petunjuk dalam narasi berikut.

Dua tahun Roesmini turut di Digul bersama Soedjito, dan baru 7 bulan saja Soedjito hidup dengan zonder bini dan anak.... (Wiranta, 2000: 15)
Dari kutipan tersebut, diketahui bahwa Soedjito setidaknya telah berada di Digul dalam waktu 2 tahun 7 bulan. Kemudian, penulis memberikan petunjuk lain. Dalam bulan ke tujuh itu, Soedjito menerima sepucuk surat dari istrinya yang bertiti mangsa 14 Juni 1929 (Wiranta, 2000: 16). Rencana pelarian itu digagas Soedjito tidak lama setelah menerima surat itu. Dengan demikian, pelarian ketujuh orang buangan itu terjadi pada tahun 1929.

\section{Ruang}

Penulis mengungkapkan ruang melalui judul yang menurut Toer (Wiranta, 2001: x) novel ini diterbitkan dengan judul Antara Hidup dan Mati atau Buron dari Boven Digul. Ruang itu begitu penting, sehingga penulis menambahkan judul kedua yang memuat aspek ruang, yaitu Digul.

Aspek ruang juga sudah dimunculkan oleh penulis dalam dialog pembuka novel tersebut.

"Bukan, kalau umpamanya nyeberangin kali Digul, sampean sanggup?” (Wiranta, 2000:1)

Digul merupakan daerah pembuangan yang membuat sengsara (Wiranta, 2000: 5). Tokoh Amat menggambarkan Digul sebagai satu tempat di hutan yang hanya dihuni kaum lelaki. Tempat yang menyiksa untuk dijalani. Mati sekalipun dianggap lebih baik daripada hidup di sana.

"Hidup dan mati, ya..., kalau dipikir lebih panjang lagi, dari pada musti hidup di tempat yang macam begini, yang Cumabiasmakan..., pikirandanmatatidakadaobatnya..., dalam satu tempat dikelilingi dengan semua hutan..., satu tempat rakyatnya cuma lelaki, buat apa hidup, toh lebih baik mati... (Wiranta, 2000: 4).

Untuk orang buangan yang masih hidup, hidup di dalam bui dianggap lebih baik daripada hidup di Digul.

Kendati mereka ada dalam bui, yang semua orang akan seram lihat itu neraka dunia, tapi bagi mereka ada satu surga, tidak saja mereka dapat makanan yang sederhana yang tidak bisa didapat di hutan, tapi yang mereka pikirkan ialah setelah 6 bulan, mereka akan bisa jadi rakyat di itu negeri, dan sudah tentu 
mereka akan bisa teruskan cita-citanya yang mereka anggap mulia (Wiranta, 2000: 89).

Hidup dibui dijamin dengan ketersediaan makanan. Dan lebih penting lagi adanya harapan untuk bebas. Sementara dibuang ke Digul tidak memberikan harapan akan bebas karena tidak jelasnya tuntutan dan hukuman.

Ruang lainnya dimunculkan untuk memperkuat lokasi Digul yang dekat dengan Nieeuw-Guinea. Ketika Kamlin merasa ragu dengan rencana pelarian, Soedjito meyakinkan bahwa dia sudah mengetahui rute pelarian dengan membuka

...satu salinan kartu Nieeuw-Guinea dari tophografisch-dients (2000: 7).

Para pelarian itu berencana untuk melarikan diri ke perbatasan, tepatnya di kali Flay, dan melintas sampai ke daerah jajahan Inggris. Di daerah itu mereka meyakini tidak akan dijangkau oleh aparat Hindia Belanda.

Satu hari persis dari itu tempat, di mana mereka ada nginap dengan bekal itu daging ular sudah sampai di kali Flay, ialah batas jajahan Belanda dan jajahan Inggris (Wiranta, 2000: 80).

Dalam pelarian mereka harus melewati daerah penduduk, yang dikenal sebagai suku KayaKaya.

"Ini dia...kampungnya kita punya sobatsobat!" teriak orang dalam perahu.

"Hati-hati dengan ini," Soedjito bilang, "Siapa tahu itu orang Kaya-Kaya sangka musuh pada kita, dan...ia pasang panahnya!" (Wiranta, 2000: 54)

Mereka sudah mempersiapkan tembakau sebagai tanda persahabatan untuk raja dan anggota suku tersebut.Hal itu tidak mengurangi kewaspadaan mereka.

Satu perkataan atau satu tertawa yang dikeluarkan oleh itu orang Kaya-Kaya, selalu bikin curiga mereka, karena merek masih ingat bahwa itu orang-orang hutan, kendati macamnya seperti manusia, tapi masih suka potong leher orang dan suka makan daging manusia (Wiranta, 2000: 56).
Ya, pelarian itu mendengar kabar bahwa suku asli di Papua masih memiliki tradisi kanibal. Namun, Soedjito meyakinkan mereka bahwa hal itu tidak sepenuhnya benar. Soedjito meyakini hal itu berdasarkan artikel seorang pastor di Merauke yang dimuat di surat kabar De Koerier (Wiranta, 2000: 58)

"Hal itu tidak berbahaya, sebab ini serombongan Kaya-Kaya di Karikou bukan dari segolongan orang yang suka potong kepala... Dan lagi sampean kalau mau tahu perkara itu potong kepala, sebetulnya tidak sembarangan kepala orang lantas dipotong, tapi kepala dari musuh mereka saja... (Wiranta, 2000: 58).

Penulis kemudian memunculkan aspek ruang yang lebih detail berkaitan dengan suku Kaya-Kaya. Orang suku Kaya-Kaya hidup dalam sebuah kampung.

Dalam itu kampung yang mereka sebut itu kampung Karikou cuma ada sejumlah kurang lebih dari seratus jiwa, dengan terdiri atas 3 rumah besar, yang mana itu bisa cukup buat mereka semua tidur dan lain-lainnya.

Rumahnya terbikin dari tiang kayu di tengah dengan satu pohon kayu yang Cuma dipotong tengah-tengahnya, dan yang lainnya Cuma sebagai penolong;pakai dinding dari kayu yang pakai lobang-lobang bundar, buat tengok barangkali ada bahaya atau musuh, sedang itu rumah besar tingginya tidak kurang dari 3 meter, di kolong itu rumah ditempati babi peliharaan dan ajing, karena babi dan anjing di sana sudah menjadi satu sobat yang kekel (Wiranta, 2000: 57).

Meskipun, Soedjito sudah meyakinkan, kawan-kawannya tetap merasa ketakutan. Ketika suku itu sedang melakukan sejenis "pesta", pelarian itu memutuskan untuk melarikan diri dan melanjutkan perjalanan. Namun, rencana mereka tercium juga. Suku itu mengejar mereka dan menyebabkan seorang pelarian terkena panah serta dua lainnya terpisah dari rombongan.

Mereka kemudian melanjutkan perjalanan hingga kali Fay. Mereka tiba di sebuah daratan dan ditemukan oleh tiga orang pribumi yang membawa senapan. Mereka kemudian dibawa 
ke rumah orang Inggris yang ternyata tuan dari ketiga orang bersenjata tadi. Mereka kemudian dijamu dan dibolehkan bermalam. Namun keesokan harinya...

Pukul 7 paginya itu tiga tamu dibangunin, karena disuruh oleh Tuannya, itu tiga tamu akan dibawa naik motor-boat ke ThursdayEiland (Wiranta, 2000: 88).

Mereka ternyata diserahkan kepada petugas. Mereka diperiksa. Karena memasuki wilayah itu secara ilegal, mereka dihukum 6 bulan penjara. Mereka tidak kaget karena sudah memperhitungkan risiko itu.

Enam bulan, ya, enam bulan, mereka akan menantikan dengan gembira, tapi...baru saja 14 hari tinggal di dalam bui, pada suatu pagi mereka dibawa keluar oleh penjaga itu bui, yang lantas dibawa ke kantor yang dulu mereka diperiksa (Wiranta, 2000: 90).

Bahkan, mereka sudah memperhitungkan jika harus bekerja dan menyeberang ke negara lain yang berbatasan, yaitu Australia.

"Setelah kita keluar dari bui, kita musti cari kerjaan dulu," Soedjito bilang.

"Dan sudah tentu kalau sudah cukup uangnya kita bisa naik kapak ke Australia...." (Wiranta, 2000: 89).

Nama Australia disebutkan oleh penulis untuk memperjelas posisi Digul dalam konteks yang lebih luas. Nama itu juga penting karena kelak para eks-Digulis menyusun kekuatan antikolonial di sana.

Namun, yang mengagetkan mereka ternyata mereka dihadapkan kepada aparat militer yang sudah mereka kenal di Digul.

Dengan kaget mereka lihat banyak militer itu di kantor, dan mereka lantas dipasrahkan kepada seorang letnan, yang mana mereka sudah kenal di Digul (Wiranta, 2000: 90).

Akhirnya berakhirlah pelarian mereka. Mereka dibawa kembali ke Digul. Kisah ini pun berakhir.

Mereka dengan mengeluh duduk dalam rumahnya yang dulu, menunggu sampai temponya kapan bisa keluar dari Digul, dan dengan sabar dan tawakal mereka tunggu nasibnya dengan menyerah; pengharapan, juga pertanyaan, "Kapan bisa pulang dari... DIGUL?" (Wiranta, 2000: 91).

\section{Sejarah}

Strategi pengasingan politik dalam arti membuang seseorang ke tempat yang jauh dari tanah asalnya karena alasan politik sudah dilakukan sejak lama jauh sebelum kedatangan orang Eropa. Para raja dan pangeran sering menculik lawan politik atau anggota keluarganya untuk mencapai tujuan mereka. Kedatangan VOC pada abad ketujuh belas membuat praktik semacam itu semakin marak dan sistematis (http://hilmarfarid.org/pengasingan-dalampolitik-kolonial/).

Strategi itu dilanjutkan pemerintah Hindia Belanda antara lain dengan membuat tempat pengasingan di Boven Digul. Boven Digul terletak di hulu Sungai Digul, Papua bagian selatan. Wilayah ini semula diselimuti oleh hutan lebat, rawa-rawa, dengan beraneka binatang buas. Wilayah ini sudah dihuni oleh penduduk asli yang masih sangat sederhana dan masih menjalankan praktik pengayauan dan kanibalisme (Handoko, 2016: 82).

Wilayah itu diputuskan sebagai tempat pengasingan dalam pertemuan luar biasa Dewan Hindia Belanda (Raad van NederlandschIndie) 18 November 1926 (Shiraishi, 2001: 3). Pertemuan itu digelar untuk merespons peristiwa pemberontakan komunis yang mulai terjadi pada 12 November 1926.

Sejak Maret 1927 para tahanan mulai dikirim ke Digul. Meskipun sasaran awalnya para pemberontak komunis, pemerintah kolonial mengasingkan juga aktivis lain yang dianggap melawan pemerintah, termasuk Wiranta.

Biodata Wiranta tercatat dalam buku Citra dan Perjuangan Perintis Kemerdekaan (Toer, 2001: xvii). Di Digul ia tercatat sebagai pemimpin pertama organisasi Kunst, Sport en Voetbal Vereeniging Digul, yang antara lain anggota pemainnya Hatta dan Sjahrir.

Menurut Rosidi (2000: 146) Wiranta ditangkap dan dihukum setahun karena persdelict atas artikelnya, "Tan Malaka 
Dibuang”. Kemudian, tahun 1927-1931 iadibuang ke Digul bersama ratusan orang yang dianggap makar terhadap pemerintah. Wiranta lahir di Sumedang tahun 1902 dan meninggal di Bandung 1983. Tahun 1917 menjadi guru di Sukabumi. Setelah memperoleh diploma boekhouding A padatahun 1922, ia bekerja sebagai assistant boekhouder di Karawang. Pada tahun 1925 ia pindah ke Bandung dan memimpin mingguan berbahasa Sunda.

Sekembali dari Digul, Wiranta aktif dalam dunia pers, antara lain dalam surat kabar Kiauw Po (Bandung), Sinar Pasundan (Bandung), Matahari (Semarang), Keng Po (Jakarta), majalah Bijaksana. Ia juga menulis dengan mempergunakan berbagai nama samaran, seperti Kaimo dan Caraka. Selain menulis Antara Idup dan Matiatawa Burondari Boven-Digoel, ia juga menulis karya-karya dalam bahasa Sunda.

Pada masa pendudukan Jepang, Wiranta ditangkap Jepang dengan tuduhan mengadakan gerakan perlawanan dan dibebaskan pada Agustus 1945. Setelah bergabung dengan pemuda pejuang kemerdekaan di Cianjur sampai tahun 1949, Wiranta kembali menjadi guru di Bandung.

Apakah Wiranta pernah melarikan diri sebagaimana kisah yang ditulisnya? Tidak ada referensi yang mendukung hal itu. Meskipun demikian, kisah penghuni tempat pengasingan Digul yang melarikan diri bukan hal asing. Matanasi menulis kisah Thomas Najoan yang berusaha melarikan diri dari Digul pada tahun 1929 (https://tirto.id/thomas-najoan-raja-kaburboven-digoel-czU4). Berkali-kali ia mencoba kabur sampai dikabarkan hilang di hutan pada percobaan keempat kalinya tahun 1942 (Handoko, 2016: 87).

Sebagai sastrawan tentu Wiranta tidak harus mengalami sendiri apa yang ditulisnya. Menurut Aristoteles (Hutceon, 2004:106), sejarawan hanya dapat berbicara tentang apa yang telah terjadi, khususnya tentang masa lalu. Sementara itu, sastrawan berbicara tentang apa yang bisa atau mungkin terjadi dan menjadikannya hal yang universal.
Wiranta melakukan itu dan menulis tentang apa yang bisa atau mungkin terjadi dalam episode sejarah Digul. Sekaligus ia menyampaikan bahwa kemungkinan itu dapat terjadi dalam sebuah pelarian di episode sejarah manapun dan di mana pun.

\section{PENUTUP}

Penelitian ini bertujuan untuk meneliti cara waktu dan ruang dinarasikan oleh penulis, sehingga aspek sejarah terungkap. Melalui uraian pada bagian pembahasan diketahui cara penulis menarasikan aspek waktu dan ruang dalam novel Buron dari Digoel.

Aspek waktu yang diungkapkan adalah waktu linear. Waktu dinarasikan dalam uraian verbal yang merujuk pada jam, hari, bulan, dan tahun. Jam dan hari dinarasikan untuk mengungkap kisah lamanya pelarian dari tempat pengasingan Digul. Bulan dan tahun dinarasikan untuk mengungkap lamanya pelarian itu selama tinggal di tempat pengungsian Digul dan waktu terjadinya peristiwa itu.

Aspek ruang dinarasikan dalam uraian verbal yang merujuk pada tempat yang bernama Digul. Tempat itu dinarasikan dalam bentuk nama tempat, nama suku yang mendiami tempat itu, juga nama-nama tempat lain yang memperjelas Digul dalam konteks yang lebih luas.

Uraian kedua aspek itu berhasil membawa pembaca pada konteks sejarah Indonesia dalam novel tersebut. Konteks tersebut adalah sejarah pengasingan para tokoh nasional ke tempat pengasingan Boven Digul oleh pemerintah Hindia Belanda.

Penelitian karya sastra yang memuat aspek sejarah dan budaya perlu terus dilakukan. Hal itu dapat memberikan pemahaman yang lebih luas terhadap aspek sejara dan budaya dalam masyarakat.

\section{DAFTAR PUSTAKA}

Coser, L.A., et al. (1991). Introduction to Sociology. Third Edition. San Diego: Harcourt Brace Jovanovich. 
Farid, Hilmar. (2013), Pengasingan dalam Politik Kolonial.(http://hilmarfarid.org/ pengasingan-dalam-politik-kolonial/). Diakses 10 Januari 2018.

Handoko, Susanto T. (2016), "Boven digoel dalam Panggung Sejarah Indonesia: dari Pergerakan Nasional Hingga Otonomi Khusus Papua. JurnalSejarah Citra Lekha, Volume 1, Nomor 2, 2016, halaman 8192.

Hidayat, Asep Rahmat. (2016), “Dayak Abad Ke-19 dalam Novel Desersi".Jurnal Sirok Bastra, Volume 4, Nomor 1, 2016, halaman 89-99.

Hutcheon, Linda. (2004), A Poetic of Postmodernism: History, Theory, Fiction. Taylor and Francis e-library.

Kuntowijoyo. (1987), Budaya dan Masyarakat. Yogyakarta: Tiara Wacana.

Llewellyn Mark and Ann Heilmann (Ed.) (2007), Metafiction and Metahistory in Contemporary Women's Writing. New York: Palgrave Macmillan.

Matranasi, Petrik. (2017), "Thomas Najoan: Raja Kabur Boven Digoel”. (https://tirto.id/ thomas-najoan-raja-kabur-boven-digoelczU4). Diakses 12 Januari 2018.
Neuman, W. L. (2003), Social Research Methods: Qualitative and QuantitativeApproaches. Fifth edition. Boston: Allyn and Bacon.

Ratna, NyomanKutha. (2010). Sastra dan Cultural Studies Representasi Fiksi dan Fakta. Yogyakarta: Pustaka Pelajar.

Rosidi, Ajip. dkk. (2000), Ensiklopedi Sunda: Alam, Manusia, dan Budaya. Jakarta: Pustaka Jaya.

Shiraishi, Takashi. (2001), Hantu Digoel: Politik Pengamanan Politik Zaman Kolonial. Yogyakarta: LKiS.

Toer, Pramoedya Ananta. (2001), Cerita dari Digul. Jakarta: KPG.

Wildandkk. (2015), "Fakta Sejarah dalam Novel Perempuan Keumala Karya Endang Moerdopo", Jurnal Cendekia, Volume 9, Nomor 1, 2015, halaman 25-36.

Wiranta. (2000), Boerondari Digoel. Magelang:Tamboer Press.

Wiyatmi. (2012), Representasi Sejarah Sosial Politik Indonesia dalam Novel-Novel Karya Ayu Utami. Yogyakarta: UNY. 